\title{
TINJAUAN KANDUNGAN BAKTERI E. coli PADA SUSU KEDELAI DI PASAR KLIWON KARANG LEWAS TAHUN 2016
}

\author{
Septian Indra Manto ${ }^{1)}$, Nur Hilal' ${ }^{2)}$ \\ Jurusan Kesehatan Lingkungan, Politeknik Kesehatan Kemenkes Semarang, \\ Jl. Raya Baturaden KM 12 Purwokerto, Indonesia
}

\begin{abstract}
Abstrak
Susu kedelai merupakan salah satu hasil dari olahan kedelai, memenuhi pangsa pasar menengah ke bawah karena kandungan yang tidak kalah dengan susu hewani dan harga relative lebih murah. Penelitian ini bertujuan mengukur kandungan bakteri E. coli pada susu kedelai di Pasar Karang Lewas. Jenis penelitian ini termasuk penelitian deskriptif dan didasarkan pada hasil observasi. Hasil Penelitian kandungan bakteri E. coli pada 8 sampel yang diperiksa yaitu 4 sampel dinyatakan memenuhi standar yakni $0 \mathrm{koloni} / \mathrm{ml}$ dan 4 lainnya tidak memenuhi standar yaitu masing-masing sampel $75 \mathrm{koloni} / \mathrm{ml}, 20 \mathrm{koloni} / \mathrm{ml}, 23 \mathrm{koloni} / \mathrm{ml}$, dan $4 \mathrm{koloni} / \mathrm{ml}$ dengan menggunakan standar dari Peraturan Kepala Badan POM RI Nomor HK.00.06.1.52.4011 tentang Penetapan Batas Maksimum Cemaran Mikroba dan Kimia dalam Makanan Tahun 2009. Kesimpulan dalam proses pembuatan susu kedelai ada 6 tahapan meliputi perendaman, perebusan, penggilingan, pemerasan, pemasakan, dan pengemasan, hasil pengukuran suhu pasteurisasi seluruhnya memenuhi standar, dan dari 8 sampel yang diperiksa, ada 4 sampel yang positif bakteri E. coli.
\end{abstract}

Kata kunci : susu kedelai, Bakteri E. coli

\section{Abstract}

Soy milk is one of the results of the processed soybean, meets the lower middle market share because the content is not lost with animal milk and the price is relatively cheaper. This study aims to measure the concentration of E. coli bacteria in soymilk on Market Reef Lewas. This study is descriptive and based on the results of observation. Results E. coli bacterial content in 8 samples examined ie 4 samples found to comply with the standard 0 colonies $/ \mathrm{ml}$ and 4 others did not meet the standards that each sample of 75 colonies / ml, 20 colonies / ml, 23 colonies / ml ,, and 4 colonies / ml using a standard POM Head of Regulation No. HK.00.06.1.52.4011 of Determination limit of Microbial Contamination and Food Chemistry in 2009. the conclusion of the process of making soy milk there are 6 stages include soaking, boiling, grinding, extortion, cooking, and packaging, pasteurization temperature measurement results fully meet the standards, and of the eight samples tested, there are four positive samples of E. coli bacteria.

Keywords $\quad$ : Soy milk, E. coli bacteria

\section{PENDAHULUAN}

Makanan dan minuman merupakan suatu zat yang dibutuhkan untuk kelangsungan proses kehidupan manusia. Kedelai merupakan salah satu sumber protein nabati yang diolah menjadi berbagai jenis, salah satunya adalah produk olahan berupa susu. Kandungan protein kedelai sekitar dua kali kandungan protein daging, yaitu sekitar $40 \%$.

Pengolahan yang sebagian besar ikerjakan secara tradisional dan kurang higienis menyebabkan produk olahan kedelai rentan terkontaminasi oleh mikroorganisme pathogen seperti Escherichia coli. Bakteri E. coli dapat mengkontaminasi air susu kedelai melalui penggunaan alat-alat pemrosesan yang kotor, kotoran di sekitar wadah pengolahan, dan proses perebusan yang di bawah $100^{\circ} \mathrm{C}$.

Distribusi susu kedelai di Kota Purwokerto khususnya di Kecamatan Karang Lewas dapat

1) Email : septianindra190@gmail.com

2) Email : inung.nh@gmail.com pasar tradisional. Tujuan penelitian ini adalah untuk mengetahui kandungan E. coli pada susu kedelai yang dijual di pasar Kliwon Karang Lewas.

\section{BAHAN DAN METODE}

Penelitian ini dilaksanakan di Pasar Kliwon Karang Lewas yang memiliki luas wilayah \pm 3.075 $\mathrm{m}^{2}$. Waktu penelitian antara bulan November 2015 hingga Februari 2016.

Subyek dalam penelitian ini adalah kandungan bakteri Escherichia coli susu kedelai yang dijual di Pasar Kliwon Karang Lewas. Jenis data yang dikumpulkan meliputi data umum berupa gambaran umum Pasar Kliwon Karang Lewas termasuk jumlah pedagang dan data khusus berupa kandungan Bakteri E. coli pada susu kedelai. Populasi pada penelitian ini adalah semua susu kedelai yang dijajakan oleh pedagang jajanan di Pasar Kliwon Karang Lewas, sedangkan sampel adalah lima pedagang susu kedelai 
di Pasar Kliwon Karang Lewas. Sumber data adalah data primer yang diperoleh dari pemeriksaan bakteri E. coli di Laboratorium Kesehatan Lingkungan Kampus 7 Poltekkes Kemenkes Semarang dan data sekunder yang diperoleh dari kantor Pasar Kliwon Karang Lewas. Cara pengumpulan data berupa pemeriksaan laboratorium dan dokumentasi untuk mendapatka data dari kantor Pasar Kliwon Karang Lewas.

Analisis data menggunakan analisis deskriptif yaitu analisis terhadap data yang ada pada tabel kemudian membandingkan dengan teori sesuai Peraturan Kepala Badan POM RI Nomor Hk.00.06.1.52.4011 Tahun 2009 dan Permenkes RI No. 1096/ Menkes/ SK/ VI/ 2011.

\section{HASIL DAN PEMBAHASAN}

\section{Cara Pembuatan Susu Kedelai}

Cara pembuatan susu kedelai menurut hasil observasi salah satu produsen susu kedelai yang menyuplai produknya ke pasar Kliwon Karang lewas, diketahui ada 6 proses pembuatan susu kedelai, sebagai berikut:

1. Perendaman

Tahapan perendaman dilakukan \pm 6-8 jam menggunakan air bersih. Kedelai yang digunakan adalah kedelai putih dan biasanya yang dipilih kedelai impor karena ukurannya yang lebih besar dibanding kedelai lokal. Sebelum dilakukan proses perendaman, kedelai akan dicuci dengan cara manual hal ini memungkinkan kontaminasi E.coli jika tangan tidak bersih dan air yang digunakan tidak steril.

2. Perebusan

Tahapan perebusan ini bertujuan agar kedelai lebih mudah untuk digiling sehingga proses penggilingan akan lebih sempurna. Perebusan dilakukan setengah matang sampai kedelai mengluarkan buih, jika perebusan sampai matang maka susu kedelai yang dihasilkan akan tidak baik.

3. Penggilingan

Proses penggilingan dilakukan menggunakan alat blender dengan perbandingan 1 : 3, 1 takaran kedelai ditambah 3 takaran air. Blender/giling kedelai sampai halus \pm 8-10 menit.

4. Pemerasan

Proses pemerasan dilakukan dengan cara manual dengan bantuan selembar kain yang dilipat secara khusus. Proses ini sangat potensial untuk terjadinya proses kontaminasi jika Personal Hygiene produsen tidak dijaga karena proses ini kontak langsung dengan tangan penjamah.

5. Pemasakan

Proses pemasakan atau pasteurisasi dilakukan selain untuk memasak susu kedelai juga bertujuan untuk membunuh bakteri yang terkandung pada susu kedelai mentah yang didapatkan saat proses perendaman sampai proses pemerasan. Berdasarkan hasil pengukuran didapatkan hasil bahwa seluruh sampel dimasak sampai suhu $>90^{\circ} \mathrm{C}$, oleh karena bakteri yang ada di susu kedelai akan mati pada tahapan ini dan bisa dikatakan kandungan E.coli pada proses pasteurisasi adalah nol.

6. Pengemasan

Proses pengemasan dilakukan dengan cara manual, oleh karena itu proses ini memungkinkan terjadinya kontaminasi seiring berjalannya proses pengemasan karena ada kontak dengan tangan dan pengemasan dilakukan ditempat terbuka. Hal inilah yang menjadi penyebab kenapa dalam satu produsen terdapat perbedaan hasil pemeriksaan bakteri E.coli karena jika proses pengemasan dilakukan dibagian awal dan suhu masih panas dan belum banyak terkena kontak dengan tangan maka hasil pemeriksaan negatif ketika suhu Susu Kedelai sudah mulai berkurang dan bertambahnya kontak dengan tangan memungkinkan terjadinya kontaminasi bakteri E.coli pada susu kedelai sebelum pengemasan.

\section{Mengukur Suhu Perebusan Susu Kedelai/ Pasteurisasi}

Hasil pengukuran suhu pasteurisasi pada salah satu Produsen Susu Kedelai yang menitipkan produknya ke Pedagang Jajanan di Pasar Kliwon Karang Lewas yakni : Pn; Yn ; Kn, Sebagai berikut: Tabel 4.2 Hasil pengukuran suhu pasteurisasi pada produsen susu kedelai

\begin{tabular}{clcl}
\hline No & Pengukuran & Suhu & Keterangan \\
\hline 1 & $\begin{array}{l}\text { Pengukuran } \\
\text { ke-1 }\end{array}$ & $95,00^{\circ} \mathrm{C}$ & $\begin{array}{l}\text { Memenuhi } \\
\text { standar }\end{array}$ \\
2 & $\begin{array}{l}\text { Pengukuran } \\
\text { ke-2 }\end{array}$ & $94,41^{\circ} \mathrm{C}$ & $\begin{array}{l}\text { Memenuhi } \\
\text { standar }\end{array}$ \\
3 & $\begin{array}{l}\text { Pengukuran } \\
\text { ke-3 }\end{array}$ & $98,00^{\circ} \mathrm{C}$ & $\begin{array}{l}\text { Memenuhi } \\
\text { standar }\end{array}$ \\
4 & $\begin{array}{l}\text { Pengukuran } \\
\text { ke-4 }\end{array}$ & $93,00^{\circ} \mathrm{C}$ & $\begin{array}{l}\text { Memenuhi } \\
\text { standar }\end{array}$ \\
5 & $\begin{array}{l}\text { Pengukuran } \\
\text { ke-5 }\end{array}$ & $97,80^{\circ} \mathrm{C}$ & $\begin{array}{l}\text { Memenuhi } \\
\text { standar }\end{array}$ \\
\hline
\end{tabular}

Standar suhu Pasteurisasi adalah $80-100^{\circ} \mathrm{C}$

Hasil pengukuran susu kedelai saat proses perebusan atau biasa disebut dengan proses pasteurisasi didapatkan hasil bahwa dari 5 kali pengukuran semuanya berada diatas $90^{\circ} \mathrm{C}$. Hasil ini sudah memenuhi syarat suhu pasteurisasi yakni 80$100^{\circ} \mathrm{C}$, dengan suhu diatas $90^{\circ} \mathrm{C}$ proses ini dapat membunuh bakteri E.coli karena bakteri tersebut termasuk bakteri Mesofilik dengan kemampuan untuk hidup disuhu maksimum $40-45^{\circ} \mathrm{C}$, jadi kemungkinan besar di tahapan pasteurisasi ini proses terjadinya kontaminasi tidak ada atau bisa dikatakan susu kedelai pada tahap perebusan (pasteurisasi) masih steril. 


\section{Pemeriksaan E.coli}

Hasil pemeriksaan pada sampel yang telah diambil dari masing-masing pedagang jajanan di pasar Kliwon Karang Lewas, pemeriksaan bakteri E.coli dilakukan di Laboratorium Kesling Kampus 7 didapatkan hasil sebagai berikut:

Tabel 4.3. Hasil pemeriksaan bakteri E.coli pada sampel Susu Kedelai dengan menggunakan seri 7 (5 11 1)

\begin{tabular}{ccccccc}
\hline No. & $\begin{array}{c}\text { Kode } \\
\text { Sampel }\end{array}$ & $\begin{array}{c}\text { Hasil } \\
\text { Penguku- } \\
\text { ran }\end{array}$ & $\begin{array}{c}\text { Stan- } \\
\text { dar }\end{array}$ & Satuan & Ket. \\
\hline 1 & Pr & 0.1 & 0 & & Koloni/ml & MS \\
2 & Pr & 0.2 & 75 & & Koloni/ml & TMS \\
3 & Kn & 0.1 & 20 & & Koloni/ml & TMS \\
4 & Kn & 0.2 & 23 & & Koloni/ml & TMS \\
5 & Yn & 0.1 & 4 & $<3$ & Koloni/ml & TMS \\
6 & Yn & 0.2 & 0 & & Koloni/ml & MS \\
7 & Pn & 0.1 & 0 & & Koloni/ml & MS \\
8 & Pn & 0.2 & 0 & & Koloni/ml & MS \\
\hline
\end{tabular}

* Peraturan Kepala Badan Pengawas Obat Dan Makanan Republik Indonesia Nomor HK.00.06.1.52.4011 Tentang Penetapan Batas Maksimum Cemaran Mikroba Dan Kimia Dalam Makanan Tahun 2009.

MS : Memenuhi Syarat

TMS : Tidak Memenuhi Syarat

Hasil pemeriksaan pada tabel tentang kandungan Bakteri E.coli ada 4 sampel yang positif E. coli, dari ke-4 sampel yang positif diketahui dari 3 pedagang yakni Pr 1 sampel, Kn 2 sampel dan Yn 1 sampel. Dari hasil ini hanya sampel dari Pn yang negatif. Jika dilihat dari tabel 4.3 ada 2 pedagang yang masingmasing sampel ada yang positif dan negatif, yaitu: $\mathrm{Pr}$ (0,75 koloni/ ml) dan Yn (0,4 koloni ml).

Berdasarkan hasil pemeriksaan bakteri E.coli pada susu kedelai yang dijual di pasar Kliwon Karang Lewas diketahui bahwa dari 8 (delapan) sampel yang diperiksa, ada 4 (empat) sampel yang positif/tidak memenuhi syarat, karena jumlah kandungan bakteri E.coli $>3$ koloni/mL dilihat pada Tabel 4.3 Hasil pemeriksaan bakteri E.coli pada sampel susu kedelai dengan menggunakan seri 7 (5 1 $1)$.

Berdasarkan tabel 4.3 ke-4 sampel yang positif diketahui dari 3 pedagang yakni Pr 1 sampel, Kn 2 sampel dan Yn 1 sampel. Dari hasil ini hanya sampel dari Pn yang negatif. Hasil lain menunjukkan ada 2 pedagang yang masing-masing sampel ada yang positif dan negatif, yaitu : $\operatorname{Pr}(0,75 \mathrm{koloni} / \mathrm{ml})$ dan Yn (0,4 koloni ml). Jika demikian ada selisih yang sangat jauh dari sampel dari Pr karena satu sampel negatif (0) sedangkan satunya positif (75 koloni/ml).

Dari analisis peneliti melihat hasil pemeriksaan disesuaikan dengan hasil observasi, data umum dan teori yakni hasil sampel susu kedelai dari 1 pedagang memungkinkan terdapat hasil yang berbeda karena semua proses pembuatan masih menggunakan cara manual salah satunya dalam proses pengemasan sehingga waktu yang dibutuhkan sedikit lama, sehingga suhu menjadi turun/dingin dan berisiko terjadinya kontaminasi silang karena proses pengemasan dilakukan di ruangan terbuka.

Produsen juga melakukan proses pembuatan susu kedelai dibantu oleh lebih dari satu orang. Hal ini juga memungkinkan menjadi salah satu penyebab mengapa satu pedagang terdapat hasil yang berbeda, karena karyawan(penjamah) tidak menggunakan APD dan masing-masing personal hygiene karyawan berbeda satu sama lain. Selain itu produsen susu kedelai dalam satu kali produksi menghasilkan \pm 500-700 pack dan masing-masing pack berisi 5 bungkus susu kedelai dan alat yang digunakan jumlahnya sangat terbatas, jadi hasil pemeriksaan dari pack pertama dengan pack yang terakhir kemungkinan akan berbeda karena alat yang digunakan sama dan hanya dibilas dengan air untuk mengganti setiap baskom. Baskom yang digunakan dapat menampung \pm 20 -40 liter dan baskom yang dipakai ada 5 buah.

Pedagang jajanan juga ada yang memiliki 2 distributor jadi sampel yang diambil dari pedagang memungkinkan dari 2 distibutor yang berbeda sehingga hasil pemeriksaan kandungan bakteri escherichia coli pada satu pedagang memungkinkan hasil yang berbeda.

\section{KESIMPULAN}

Terdapat 6 proses pembuatan susu kedelai. Tahapan-tahapan pembuatan susu kedelai meliputi: perendaman, perebusan, penggilingan, pemerasan, pemasakan dan pengemasan. Pembuatan susu kedelai yang dijajakan dipasar Kliwon menggunakan cara manual, hanya pada tahapan penggilingan yang menggunakan bantuan alat yakni blender dan produsen susu kedelai tidak menggunakan APD saat melakukan produksi.

Hasil pengukuran suhu pemasakan atau pasteurisasi pada salah satu produsen susu kedelai yang menjadi distributor susu kedelai kepedagang jajanan pasar Kliwon Karang Lewas semuanya memenuhi standar. Dari 5 kali pengukuran suhu pasteurisasi $>90^{\circ} \mathrm{C}$ sedangkan persyaratan suhu pasteurisasi adalah $80-90^{\circ} \mathrm{C}$.

Hasil pemeriksaan bakteri E.coli didapatkan ke4 sampel yang positif diketahui dari 3 pedagang yakni Pr 1 sampel, Kn 2 sampel dan Yn 1 sampel. Dari hasil ini hanya sampel dari Pn yang negatif. Hasil lain menunjukkan ada 2 pedagang yang masing-masing sampel ada yang positif dan negatif, yaitu: $\operatorname{Pr}(0,75$ koloni/ ml) dan Yn (0,4 koloni ml). Jika demikian ada selisih yang sangat jauh dari sampel dari Pr karena satu sampel negatif (0) sedangkan satunya positif (75 koloni/ml). Faktorfaktor yang menjadi penyebab adanya kandungan escherichia coli pada susu kedelai adalah cara pembuatan, alat yang digunakan, penjamah dan tempat produksi. 
Saran sebaiknya dibuat ruangan khusus untuk proses pengemasan dan dibuat tertutup, produsen menggunakan APD yang sesuai, menjaga kebersihan ruang produksi, dan mengikuti pelatihan kesehatan pangan. Kepada Dinas Kesehatan diagendakan untuk pelatihan tentang kesehatan pangan dan personal hygiene dan pengusaha diberikan edukasi tentang pembuatan produk tertentu yang benar.

\section{DAFTAR PUSTAKA}

Aini, Asni Nurul, dkk. 2010. "Sanitasi Makanan”. Laporan Tugas.Yogyakarta: Politeknik Kesehatan Kemenkes Yogyakarta

Anonim. 2000. Susu Kedelai. Jakarta: Kantor Deputi Menegristek Bidang Pendayagunaan dan Pemasyarakatan Ilmu Pengetahuan dan Teknologi

Anonim. 2005. Kamus Besar Bahasa Indonesia. Jakarta: Balai Pustaka14

Anwar dkk. 1989. Pedoman Bidang Sanitasi Makanan dan Minuman. Jakarta : Pusat Pendidikan Tenaga Kesehatan Departemen Kesehatan RI.

Anwar, Soedarso, dkk, 1987, Sanitasi Makanan dan Minuman pada Istitusi Pendidikan Tenaga Sanitasi, Jakarta: Departemen Kesehatan Republik Indonesia.

Arisman,. 2009, Keracunan Makanan:Buku Ajar Ilmu Gizi, Jakarta:EGC

Fathonah Siti. 2005. Hygiene dan Sanitasi Makanan. Semarang : Unnes Press.

Kukuh. 2007. Studi kandungan bakteri coliform dan sanitasi peralatan es campur pada Pedagang Kaki Lima Sekolah Dasar di Kecamatan Kembaran tahun 2007. KTI. Jurusan Kesehatan Lingkungan. Politeknik Kesehatan Kemenkes Semarang.
Michael J. Pelczar, \& E.C.S Chan, 2008, Dasar-dasar Mikrobiologi revisi kedua, Jakarta: Universitas Indonesia

Mukono, 2008, Prinsip Dasar Kesehatan Lingkungan Edisi ke dua, Surabaya: Airlangga University Press

Nurwanto dan Abas siregar, 1997, Mikrobiologi Pangan hewan dan nabati, Yogyakarta: Kanisus

Purbowarsito. 2011. Uji Bakteriologis Air Sumur di Kecamatan Semampir Surabaya. Skripsi Sains Bidang Biologi, Fakultas Sains dan Teknologi, Universitas Airlangga

Srikandi Fardiaz. 1992. Analisis Mikroba Pangan 1. Jakarta: Gramedia Pustaka Utama.

Suharsimi Arikunto, 1998, Prosedur Penelitian Suatu Pendekatan Praktek, Jakarta : Rineka Cipta

Suharsimi Arikunto, 1998, Prosedur Penelitian Suatu Pendekatan Praktek, Jakarta : Rineka Cipta Surat Keputusan Dir Jen POM No. HK.00.06.1.52.4011 Tahun 2009 tentang penetapan batas maksimum cemaran mikroba dan kimia dalam makanan adalah negative (nol).

Tri Cahyono, 2012, Pedoman Penulisan Proposal Penelitian Dan Karya Tulis Ilmiah/Skripsi Edisi Revisi Kedua, Purwoketo: Kementerian Kesehatan RI

Politeknik Kesehatan Semarang Jurusan Kesehatan Lingkungan Purwokerto .

Wahit Iqbal Mubarak dan Nurul Chayatin, 2009, Ilmu Kesehatan Masyarakat:Teori dan Apilikasi, Jakarta:Salemba Medika 